\title{
TRANSPLANTATION, LEGAL ADOPTION, HARMONIZATION OF OMNIBUS LAW AND INVESTMENT LAW
}

\author{
Syprianus Aristeus \\ Researcher of Badan Penelitian dan Pengembangan Hukum dan Hak Asasi Manusia, \\ Kementerian Hukum dan Hak Asasi Manusia Republik Indonesia, Jakarta. \\ Corresponding author. Email: syprianusaristeus@gmail.com \\ Paper received on: 02-10-2021, Revised on: 06-12-2021, Approved to be published on: 07-12-2021; \\ DOI: http://dx.doi.org/10.30641/dejure.2021.V21.507-516
}

\begin{abstract}
The best way in an effort to manage investment is by transplanting, adopting laws, harmonization by making breakthroughs to existing regulations, such as in the case of implementing the Job Creation Law. The Omnibus Law offered by the government as a "practical and pragmatic" solution is a political and legal policy to cut various regulatory barriers, to simplify bureaucracy, to accelerate services, to increase efficiency, to increase competitiveness, and to prevent opportunities for corrupt behavior. The government must evaluate this law (Job Creation) where there is still overlap without regard to regulations. The statement of the problem in this scientific paper is why there is a conflict of interest and regulations that are not in accordance with the laws and regulations? As normative juridical research, this research is based on an analysis of legal norms. The Omnibus Law is a political product. In the process of its discussion, the law resulted from a political process. The government must evaluate this law (Job Creation) where in the process of making it there is still overlap without regard to regulations.
\end{abstract}

Keywords: legal transplantation; legal adoption; omnibus law

\section{INTRODUCTION}

Globalization that is happening at this time has changed the order of the legal and economic fields in every country, including Indonesia. The impact of the ratification of free trade (Law Number 7 Year 1994) is seen that there is an investment invasion from one country to another. Capital that enters a country and access to a region/country occur because it is in accordance with the agreement of investors with the country where the capital is located. The government anticipates this in various ways to regulate and attract investors to come to Indonesia, with various investment convenience. One of them is by way of transplantation, adoption of law, harmonization in certain fields, and the last one is through the Omnibus Law (Job Creation Law).

Transplantation is the takeover of legal rules, legal doctrines, structures, or legal institutions from one legal system to another or from one jurisdiction to another. To emphasize this concept, transplantation is more about taking over legal rules, legal doctrines, structure or legal institutions, from the common law system to the
Indonesian legal subsystem ${ }^{1}$, while legal adoption is a phenomenon of migration of a legal rule or legal system or part of legal system from one country to another, or from one nation to another. ${ }^{2}$

Transplantation was originally introduced by Alan Watson in 1933, regarding the application of law (legal transplantation) with the proposal that no life is perfect without society and law on earth. Therefore, transplantation or harmonization to fill a legal vacuum in a country is unavoidable. ${ }^{3}$

As part of a colonial colony, Indonesia uses unification policies for laws and regulations. According to Sri Soemantri, he said that Dowes Deker had suggested that Indonesia start transplanting several laws and regulations with transplantation, but this was opposed by Soekarno.

\footnotetext{
Tri Budiyono, Transplantasi Hukum, Harmonisasi dan Potensi Benturan (Salatiga: Griya Media, 2009). 11

2 E. Sundari, Perbandingan Hukum dan Fenomena Adopsi Hukum (Yogyakarta: Cahaya Atma Pustaka, 2014). 84

3 Utari Maharany Barus, Transplantasi Hukum Perjanjian Menurut KUH Perdata ke dalam Hukum Perjanjian Islam pada Akad Pembiayaan Bank Syariah di Indonesia (Jakarta: Fakultas Hukum Universitas Indonesia, 2016). 589
} 
(President of the Republic of Indonesia at that time). ${ }^{4}$

In fact, the unification of national legal laws and regulations is not a new matter in the development of legal history in Western Europe. The experience of transplanting western law that can be learned from Indonesia's colonial history, including several humanitarian principles introduced from Europe, began to take on an important role in colonial rule since the early 19th century. ${ }^{5}$

If we look at this development, then the use of transplantation, harmonization and adoption of the law, laws and regulations can be continued to fill the legal vacuum, especially business law.

From the economic aspect as well as the law that regulates the behavior of economic actors, it can be concluded that globalization which is currently happening in general is not a new phenomenon. Legal transplantation has occurred since the spread of the corpus iuris civilis during the Roman era and underwent reformulation based on community practices in countries that are considered to have developed law by origin. Then, the law has spread, along with the development of a modern state to almost all countries in the world. Likewise, economic institutions, the teachings of economic doctrines that have an impact on the behavior of economic actors, were originally developed and built on the basis of five teachings on economic freedoms, namely free movement of good, free movement of person, free movement of capital, free movement of services and the principle of non-discrimination. Therefore, especially regarding the transplantation of laws that regulate the behavior of economic actors, the researcher agreed with what was stated by Alan Watson, that globalization is something that empirically cannot be avoided.

However, if the transplantation of law, especially the law that regulates the behavior of economic actors, is to be studied comprehensively, it is not enough to use the thought of Watson

4 Sri Soemantri, "Sistem Hukum Indonesia (materi kuliah Program Doktor Ilmu Hukum," (Jakarta: Fakultas Hukum Universitas Jayabaya, 2016).

5 Soetandyo Wignyo Soebroto, "Transplantasi Hukum ke Negara-negara yang tengah Berkembang Khususnya Indonesia, dalam Hukum Pradiguna, Metode dan Dinamika Masalahnya," in 70 Tahun Prof. Soetandyo Wignyo Soebroto (Jakarta: HuMA, 2002), 258. who said that "a legal rule is transplanted simply because it is a good idea" 6 as the only reason and basis of thought. Legal transplantation relates to problems and have implications for more complex problems. The experience of legal transplantation in Turkey and Japan, which tried to accommodate and provide a "marriage" space between the transplanted law and the customs of the local community, perhaps can be observed to find and build a legal transplantation model in Indonesia. ${ }^{7}$

Based on the three ways in handling the laws and regulations, the handling does not protect the efforts of investors to enter Indonesia, so the president makes a legal breakthrough by using the Omnibus Law (Job Creation Law) method.

The term Omnibus Law comes from the Common Law system, which in the Black Law Dictionary it is stated that "omnibus" is relating to or dealing with numerous objects or items at once; including many things or having various purposes. ${ }^{8}$ Meanwhile, the definition of "law" from the same source is the aggregate of legislation, judicial precedents, and accepted legal principles; the body of authoritative grounds of judicial and administrative action; esp., the body of rules, standards, and principles that the courts of a particular jurisdiction apply in deciding controversies brought before them. ${ }^{9}$

In practice, the Omnibus Law in the United States is a new law that amends several previous laws, including the regulations established in the Judicial Precedent at once. The term Omnibus Law will have different meanings in the United States and Indonesia because the Indonesian legal system comes from Civil Law, where the regulations are collected in one code so that all laws are in that code. The legal system and concrete conditions that occur in society must be a concern in using the Omnibus Law as an ideal way to overcome disharmony in laws and regulations.

A new law that is made will override several laws that are related and intersect with each other. The streamlining of several laws is carried

\footnotetext{
6 Budiyono, Transplantasi Hukum, Harmonisasi dan Potensi Benturan.. 82

Ibid.. 83

8 Ahmad Redi \& Ibnu Sina Chandranegara, Omnibus Law, Diskursus Pengadopsiannya ke dalam Sistem Perundang-undangan Nasional (Depok: Raja Grafindo Persada, 2020). 58

9 Ibid. 22
} 
out so that the purpose of making the Omnibus Law will require a legal system that can improve itself through judges' decisions in court based on concrete events.

The principle that strengthens the authority of the Omnibus Law has not yet been made. The difference in application in court lies in the legal system. Procedural law in Indonesian courts still uses the classic civil law system. The Omnibus Law will be equated with other laws. In fact, omnibus law requires a principle that can override all other laws. Judges cannot override other laws if the judges are not given the authority to elevate the Omnibus Law to a higher position than other laws.

The term Omnibus Law comes from the Common Law system, which in the Black Law Dictionary it is stated that "omnibus" is relating to or dealing with numerous objects or items at once; including many things or having various purposes. ${ }^{10}$ Meanwhile, the definition of "law" from the same source is the aggregate of legislation, judicial precedents, and accepted legal principles; the body of authoritative grounds of judicial and administrative action; esp., the body of rules, standards, and principles that the courts of a particular jurisdiction apply in deciding controversies brought before them. ${ }^{11}$

The writing of this paper focused more on investment law, which has been implemented by the government as an effort to attract investors to invest in Indonesia. The breakthrough made by the government is to reorganize several provisions of laws and regulations in the investment sector as stated in Law Number 25 Year 2007 concerning Investment.

The Investment Law (Law No. 25 Year 2007) has been amended, from previously Law on Foreign Investment (PMA) Law No. 1 Year 1967 in conjunction with Law No. 11 Year 1970, and several other related regulations (Law No. 6 Year 1968 in conjunction with Law No. 12 Year 1970).

This Investment Law applies to investment in all sectors in the territory of the Republic of Indonesia. This is as stated in Article 2 and clarified in its explanation which states that what is meant by "investment in all sectors in the territory of the

1o Bryan A. Garner, Black Law Dictionary, A Bridge, gth Edition, 9 ed. (Minnesota: West Group, 2010),. 257

1 Ibid. 258
Republic of Indonesia” is direct investment and does not include indirect investment or Portfolio.

Law Number 25 Year 2007 contains several important things which are reforms to the two previous laws, namely in the implementation of investment, it must be based on several principles as stated in Article 3 (1) of Law Number 25 concerning investment, namely:

1) Legal Certainty, namely the principle in a rule of law that lays down the law and provisions of laws and regulations as the basis for every policy and action in the investment sector.

2) Transparency, namely the principle of being open to the right of the community to obtain correct, honest and non-discriminatory information regarding investment activities.

3) Accountability, namely the principle that determines that every activity and the final result of the implementation of investment must be accounted for to the community or the people as the holder of the highest sovereignty of the state in accordance with the provisions of laws and regulations.

4) Equal treatment and without discrimination of country of origin, namely the principle of non-discriminatory service treatment based on the provisions of laws and regulations, both between domestic investors and foreign investors as well as between investors from one foreign country and investors from another foreign country.

5) Togetherness, namely the principle that encourages the role of all investors together in their business activities to realize the welfare of the people.

6) Fair Efficiency, namely the principle that underlies the implementation of investment by prioritizing fair efficiency in an effort to create a fair, conducive and competitive business climate.

7) Sustainability, namely the principle that in a planned manner strives for the development process through investment to ensure prosperity and progress in all aspects of life, both for now and for the future.

8) Environmentally conscious, namely the principle of investment carried out by still paying attention to and prioritizing the protection and maintenance of the environment. 
9) Independence, namely the principle of investment carried out by still prioritizing the potential of the nation and the state by not blocking the entry of foreign capital for the realization of economic growth.

10) The balance of progress and National Economic Unity, namely the principle that seeks to maintain a balance of regional economic progress within the national economic unity. ${ }^{12}$

Meanwhile, the implementation of investment must aim at increasing national economic growth, creating job opportunity, increasing sustainable economic development, increasing the competitiveness of the national business sector, increasing the capacity and capability of national technology, encouraging the development of the people's economy, processing the potential economy into real economic strength by using funds originating both from within the country and from abroad, and improving the welfare of the community. ${ }^{13}$

The government does not discriminate the treatment for investors who have invested in Indonesia, unless otherwise stipulated by the provisions of laws and regulations. The government also encourages the creation of a conducive national business climate for investment to strengthen the competitiveness of the national economy and to accelerate the increase in investment. ${ }^{14}$

In stipulating the basic investment policy, based on Article 4 paragraph (2) of Law Number 25 Year 2007 concerning Investment, the government must:

1) Give equal treatment to domestic investment and foreign investment by still taking into account the national interest.

2) Guarantee legal certainty, business certainty and business security for investment from the licensing process until the end of investment activities in accordance with the provisions of laws and regulations; and

3) Open opportunity for development and

\footnotetext{
12 Undang-undang Republik Indonesia No. 25 Tahun 2007 tentang Penanaman Modal, Pasal 3 ayat (1) dan Penjelasan Undang-Undang No. 25 Tahun 2007 tentang Penanaman Modal (Republik Indonesia, 2007).

13 Ibid. Pasal 3 ayat (2)

${ }^{14}$ Ibid. Pasal 4 ayat (1)
}

provide protection for micro, small and medium enterprises and cooperatives.

The same treatment for investment is given by the government to all investors originating from any country who conduct investment activities in Indonesia in accordance with the provisions of laws and regulations. The same treatment given by the government does not apply to investment from a country that obtains special rights based on an agreement with Indonesia. ${ }^{15}$

Regarding the effort made by the government by amending the Investment Law as a whole, if examined carefully, it can be seen that there has been a lack of clarity in the order of implementation in the field. Ownership of land by investors as regulated in the provisions of Article 23 of Law Number 25 Year 2007 is for \pm 100 years and can be extended for the next 99 years. The government's regulation contradicts Law Number 5 Year 1960 concerning Basic Agrarian Provisions and Government Regulation Number 40 Year 1996 concerning Building Use Rights (HGB), Use Rights (HP), and Ownership Rights (HM). All of them are limited to \pm 30 years and can be extended.

Seeing the ambiguity of the harmonization and conflict of regulations that are currently occurring, creating overlapping authorities between the central government and regional governments, what the central government must strive for by means of the Omnibus Law (Job Creation Law) is an effort by the government to require regulations that can cover "Good governance". If the regulations made are not effective nor efficient, then the government can make changes or improve them in the ways regulated in higher laws and regulations.

From the description above, then, the statement of the problem in this scientific paper is why there is a conflict of interest and regulations that are not in accordance with the laws and regulations?

\section{RESEARCH METHOD}

This research is normative juridical research. As normative juridical research, this research is based on an analysis of legal norms, both law in the sense of law as it is written in the books and statutes (in literature and laws and regulations). ${ }^{16}$

15 Ibid. Pasal 6

16 Ronald Dworkin, Legal Research (deadalus: Spring, 
The emphasis of the analysis is the legal norms contained in the literature and laws and regulations. As a support, empirical legal research was also carried out on informants who were used as resource persons.

Normative legal research on the normative side of law as a normative practical science, describes how the process of a legal decision occurs, how relevant parties fill the legal vacuum, explains vague norms, narrows the definition of a legal rule so that it can be applied to a concrete event that requires legal settlement, even to find a legal rule.

\section{DISCUSSION AND ANAL YSIS}

\section{A. Conflict of Interest and Regulations that are not in accordance with the Laws and Regulations}

Since being proclaimed by President Joko Widodo in the second term of his administration, he has seen that there are many laws and regulations that hinder reform in the investment sector.

Pratikno conveyed the government's 'complaint' regarding 'regulatory obesity' which hinders investment in Indonesia. There are fifteen Ministries that make regulations that have the potential to hinder investment. As of October 2018, there were 7,621 Ministerial Regulations, 765 Presidential Regulations, 452 Government Regulations and 107 Laws. The implications of 'Regulatory Obesity' raise new problems in the form of: (1) potential overlap; (2) harmonization and synchronization burden; and (3) there is no institution that conducts monitoring and evaluation. ${ }^{17}$ Based on the database of peraturan. go.id as of March 20, 2020, the number of regulations that we have is as follows: 180 laws, 4,553 government regulations, 2,006 presidential regulation, 26 BPK Regulations, 146 Bank Indonesia Regulations, 328 Financial Services Authority Regulations, 3,772 Ministerial Regulations, 1,596 Regional Regulations, and the total is 43,235 . This number can still increase because our regulations are always increasing and

1973).24

17 Basuki Rekso Wibowo, Undang-Undang Omnibuslaw tidak sesuai dengan regulasi peraturan perundangundangan yang ada (Makalah disampaikan dalam seminar hukum ikatan notaris Indonesia cabang Jakarta di BPHN (Jakarta, 2020). not all Ministerial Regulations, Non-Ministerial Government Institution Regulations (LPNK) and Regional Regulations are included in peraturan. go.id.

There are so many laws and regulations, both government regulations and level I-II regional regulations, which are significant enough to be replaced immediately with regulations that can attract investors. Therefore, the methods carried out using the Omnibus Law actually experience conflicts and regulatory problems.

According to Tri Budiyono ${ }^{18}$, he stated that in every enforcement of the law there must be certain expectations both from the legislators and from the community groups that are their addressee, or even other groups that have a direct or indirect interest in the problem. In reality, what is expected does not always match what happens at the praxis level. Borrowing Robert K. Merton's term $^{19}$, expectations themselves can be realized in accordance with what is expected (manifest) but can also be different from what is expected (latent). When what happens at the praxis level is not in accordance with what is expected, in essence there has been a conflict in the application of the law. The lack of judicial praxis which is the implementation of transplanted doctrines, which can be used as a reference to study this problem, causes the researcher to tend to see the potential conflict rather than the conflict itself. However, the analysis of judicial praxis that gives rise to conflicts will still be referred to in order to sharpen the view on this issue.

Meanwhile, the potential problems in the regulation of the preparation of these regulations substantially conflict with Law Number 12 Year 2011 in conjunction with Law Number 15 Year 2019. The Omnibus Law method is the concept of establishing the main law to regulate issues that have previously been regulated in a number of laws or in one law. This means not only reducing the number of laws, but also paying attention to the consistency, substance and neatness of the arrangements so that the existing procedures are

\footnotetext{
18 Budiyono, Transplantasi Hukum, Harmonisasi dan Potensi Benturan. 12-13

19 Margareth M Poloma, Contemporary Sociology Theory, di-Indonesiakan, ed. Yosogama, cetakan ke. (Jakarta: Raja Grafindo Persada, 200o). 23
} 
simpler and more targeted; and aim to strengthen the national economy. ${ }^{20}$

Omnibus Law is a practice of drafting laws and regulations, which is mostly carried out in countries that adhere to the Common Law/Anglo Saxon system such as America, Canada, England, the Philippines and others. The process is called Omnibus Legislating and the product is called the Omnibus Bill. The word Omnibus comes from Latin which means everything (for everything). Omnibus Law is a regulation or law (UU) that covers various issues or topics. Literally, the definition of Omnibus Law is the law for all. The term comes from the Latin word omnis, which means for all. Therefore, it can be concluded that the omnibus law is a new law that contains various regulatory substances whose existence amends several laws at once. ${ }^{21}$ It was further stated that the reason the government established the omnibus law was because too many regulations had been established. Most of the time, one regulation overlaps another regulation and hinders access to public services, as well as ease of doing business. This makes the program to accelerate development and improve community welfare difficult to achieve. $^{22}$

B. Analysis and Discussion in the Establishment of Law through Transplantation, Adoption, Harmonization and the Omnibus Law (Job Creation Law).

In the transitional rule of Article 1 of the 1945 Constitution, the Indonesian government has emphasized that the old law remains in effect. This can be found in the discussion of colonial law which was discussed by the National Legal Development Agency (BPHN) of the Department of Judiciary when it was led by Prof. Dr. CFG

\footnotetext{
${ }^{20}$ Basuki Reksowibowo, "Omnibus Law: sebagai Kebijakan Politik dan Hukum," in Hut Ke-7 KANIT UNDIP (Jakarta: ayasan Komunitas Cendikiawan Hukum Indonesia, 2020), 5.

${ }_{21}$ Zsazya, "Omnibus Law dan Rencana Penerapannya di Indonesia," https://www.online-pajak.com/, diakses September 10, 2021, https://www.online-pajak.com/ tentang-pph-final/omnibus-law.

22 Afhdal Mahatta, Omnibus Law: Upaya Perbaikan Proses Legislasi di Indonesia (Omnibus Law) Diskursus Pengadopsiannya ke dalam sistem Perundangundangan Nasional, ed. Ahmad Redi dan Ibnu Sina Chandranegara (Jakarta: Raja Grafindo Persada, 2020). 105-106
}

Sunaryati Hartono, who said that \pm 700 (seven hundred) colonial regulations still apply. ${ }^{23}$

According to her, the best way is by transplantation, adoption, and harmonization. But it is not a piece of cake, it takes hard work to replace it. Since the Dutch East Indies, transplantation have taken place until now although there is no compulsion for transplantation. At this time transplantation is carried out in developing countries voluntarily. ${ }^{24}$

Some of the areas of business law that have been transplanted are as follows:

1. Bankruptcy Law (Law Number 37 Year 2004)

2. Capital Market Law (Law No. 8 Year 1995)

3. Law on Prohibition of Monopolistic Practices and Unfair Business Competition (Law No. 5 Year 1999)

4. Investment Law Regulations (Law No. 25 Year 2007)

5. Limited Liability Company Law (Law No. 40 Year 2007)

6. Law of Agreement/Contract in Sharia Agreement

The things mentioned above are not different from what several countries have done by adopting laws to meet business needs, including: ${ }^{25}$

1. Class Action adoption model

2. Francking adoption model

3. NGO's legal adoption model

Even though this is happening now (Law Number 11 Year 2020 has been in effect for 3 months but it is not signed by the President and the law is declared valid), therefore globally what President Joko Widodo's government wants can be achieved, to be able to overcome the "chaotic" and "overlapping" contents of the various existing laws and regulations.

The Omnibus Law offered by the government as a "practical and pragmatic" solution is a political and legal policy to cut various regulatory barriers, to simplify bureaucracy, to accelerate services, to

\footnotetext{
${ }^{23}$ C.F.G. Sunaryati Hartono, Hukum Kolonial Tantangan bagi Pemerintah untuk Menggantikan dengan UndangUndang yang Pancasilais (Jakarta: Raja Grafindo Persada, 1996). 21

24 Ibid. 23

25 Sundari, Perbandingan Hukum dan Fenomena Adopsi Hukum.96-98
} 
increase efficiency, to increase competitiveness, and to prevent opportunities for corrupt behavior.

The Omnibus Law is a major work carried out by the government by synergizing and harmonizing as many as 177 laws into 1 (one) Omnibus Law regarding job creation. It is not an impossible thing to do, considering that the work must be done quickly even though there is conflict in terms of regulation or there is a conflict of interest in the work.

Problems in planning the establishment of laws and regulations can be divided into two: first, problem in the establishment of laws; and second, problem in planning the establishment of GovernmentRegulations,PresidentialRegulations, and Regional Regulations. The division is based on what institutions are involved in the process of planning the establishment of regulations. In planning laws, the institutions involved include two different branches of power, namely the executive and the legislature. Therefore, it is necessary to consider the implementation of the principle of checks and balances. ${ }^{26}$ Meanwhile, in the planning of Government Regulations, Presidential Regulations, and Regional Regulations, only one branch of power is involved in the process of their establishment, namely the executive power.

Regarding the planning of laws, Article 21 paragraph (4) of the Law on Establishment of Laws and Regulations Year 2011 stipulates that, "The preparation of the National Legislation Program (Prolegnas) within the Government shall be coordinated by the minister who carries out government affairs in the legal field", in which the authority is delegated to BPHN which is under the Ministry of Law and Human Rights.

The Law on Establishment of Laws and Regulations Year 2011 clearly determines who the implementing agency is, but does not explicitly state the agency's authority to review and select recommendations submitted by various parties regarding the established laws.

In addition, BPHN only plays a role in the technical aspect of the establishment of laws, but does not have the authority to determine overall policies in determining the planning of laws. The impact that occurs is that the number of bills

26 JimlyAsshiddiqie, Pengantar Ilmu Hukum TataNegara, Jilid II. (Jakarta: Sekretariat Jenderal Mahkamah Konstitusi Republik Indonesia, 2006). 21 passed into laws in one year is always less than the number of bills that are prioritized in the National Legislation Program. This is reflected in the achievements of legislation throughout the 2015-2018 period, namely when the number of bills that were passed into laws was always lower than the number of priority proposals included in the legislative planning. In fact, the achievements of legislation originating from the House of Representatives' initiative proposals only ranged from 20-30 percent of those proposed at the beginning of the year.

If it is connected to the theory of laws and regulations, then in the process of establishing a law, the interests of the nation and state should take precedence over the interests of groups, although sometimes the political side in the establishment of laws cannot be avoided. As a result, it takes quite a long time, even decades, before the law is born, while times and technology have evolved. In turn, the existence of the law is no longer relevant to the needs of the state and society because it has lost its usefulness. ${ }^{27}$

The weak authority in selecting proposed laws has an impact on inconsistent standards in the priority list. The Law on Establishment of Laws and Regulations Year 2011 requires several documents that must be included in the proposal for a bill to be included in the National Legislation Program, namely an academic document, a bill draft, and a statement that the bill draft has passed the harmonization stage. These requirements are only seen as formal completeness without looking at the substance of the document. This has also resulted in a discrepancy between the document of the planning of regulations and the document of the planning of development and legislation politics that has been outlined before.

The execution is specifically regulated in Article 200 Paragraph (11) of the amended Indonesian Reglement (HIR) which states as follows: "If a person is reluctant to leave his/her sold immovable asset, the head of the district court will make an order letter to the authorized person, to execute the bailiff's letter with the help of the clerk of the district court or a European official appointed by the head, and if necessary with the help of the police, so that the immovable asset is

7 JogiNainggolan, TeoriPeraturanPerundang-Undangan dalam Energi Hukum, Sebagai Faktor Pendorong Efektifitas Hukum (Bandung: Refika Aditama, 2015). 61 
left and emptied by the person whose asset is sold and by his relatives". ${ }^{28}$

\section{CONCLUSION}

The government's efforts to attract investors to come to Indonesia to invest by making a breakthrough for the existing laws and regulations, namely by way of Omnibus Law by not paying attention to the applicable laws and regulations will be a boomerang for the government because it can cause distrust of investors to come to Indonesia.

Omnibus Law is a political product, in the process of discussion it is produced from a political process, involving various political interest groups accompanied by political transactions and in the end the Omnibus Law ends as a political compromise.

\section{SUGGESTION}

Parties who are dissatisfied with this job creation law can file a lawsuit to the Constitutional Court. In addition, the Government must evaluate this law (Job Creation) where in the process of its establishment there is still overlap without regard to regulations.

\section{ACKNOWLEDGMENT}

The researcher would like to express gratitude to the supervisors in writing this paper so that it can be maximized in method and substance, including Mr. Ahyar Arigayo (Principal Researcher) and Muhaimin (Junior Researcher) as well as other research colleagues who provided input and suggestions in the writing process, as well as the Research and Development Board for Law and Human Rights, Ministry of Law and Human Rights, where the researcher carries out his duties as a Legal Researcher.

\section{BIBLIOGRAPHY}

Asshiddiqie, Jimly. Pengantar Ilmu Hukum Tata Negara. Jilid II. Jakarta: Sekretariat Jenderal Mahkamah Konstitusi Republik Indonesia, 2006.

\footnotetext{
${ }^{28}$ H.P Panggabean, Skematik Ketentuan Hukum Acara Perdata dalam HIR (Bandung: Alumni, 2015). 48
}

Barus, Utari Maharany. Transplantasi Hukum Perjanjian Menurut KUH Perdata ke dalam Hukum Perjanjian Islam pada Akad Pembiayaan Bank Syariah di Indonesia. Jakarta: Fakultas Hukum Universitas Indonesia, 2016.

Budiyono, Tri. Transplantasi Hukum, Harmonisasi dan Potensi Benturan. Salatiga: Griya Media, 2009.

Chandranegara, Ahmad Redi \& Ibnu Sina. Omnibus Law, Diskursus Pengadopsiannya ke dalam Sistem Perundang-undangan Nasional. Depok: Raja Grafindo Persada, 2020.

Dworkin, Ronald. Legal Research. deadalus: Spring, 1973.

Garner, Bryan A. Black Law Dictionary, A Bridge, 9th Edition. 9 ed. Minnesota: West Group, 2010.

Hartono, C.F.G. Sunaryati. Hukum Kolonial Tantangan bagi Pemerintah untuk Menggantikan dengan Undang-Undang yang Pancasilais. Jakarta: Raja Grafindo Persada, 1996.

Mahatta, Afhdal. Omnibus Law: Upaya Perbaikan Proses Legislasi di Indonesia (Omnibus Law) Diskursus Pengadopsiannya ke dalam sistem Perundang-undangan Nasional. Diedit oleh Ahmad Redi dan Ibnu Sina Chandranegara. Jakarta: Raja Grafindo Persada, 2020.

Nainggolan, Jogi. Teori Peraturan PerundangUndangan dalam Energi Hukum, Sebagai Faktor Pendorong Efektifitas Hukum. Bandung: Refika Aditama, 2015.

Panggabean, H.P. Skematik Ketentuan Hukum Acara Perdata dalam HIR. Bandung: Alumni, 2015.

Poloma, Margareth M. Contemporary Sociology Theory, di-Indonesiakan. Diedit oleh Yosogama. Cetakan ke. Jakarta: Raja Grafindo Persada, 2000.

Reksowibowo, Basuki. "Omnibus Law: sebagai Kebijakan Politik dan Hukum.” In Hut Ke-7 KANIT UNDIP, 5. Jakarta: ayasan Komunitas Cendikiawan Hukum Indonesia, 2020. 
Soebroto, Soetandyo Wignyo. "Transplantasi Hukum ke Negara-negara yang tengah Berkembang Khususnya Indonesia, dalam Hukum Pradiguna, Metode dan Dinamika Masalahnya.” In 70 Tahun Prof. Soetandyo Wignyo Soebroto, 258. Jakarta: HuMA, 2002.

Soemantri, Sri. "Sistem Hukum Indonesia (materi kuliah Program Doktor Ilmu Hukum,.” Jakarta: Fakultas Hukum Universitas Jayabaya, 2016.

Sundari, E. Perbandingan Hukum dan Fenomena Adopsi Hukum. Yogyakarta: Cahaya Atma Pustaka, 2014.

Undang-undang Republik Indonesia No. 25 Tahun 2007 tentang Penanaman Modal. Pasal 3 ayat (1) dan Penjelasan Undang-Undang No. 25 Tahun 2007 tentang Penanaman Modal. Republik Indonesia, 2007.

Wibowo, Basuki Rekso. Undang-Undang Omnibuslaw tidak sesuai dengan regulasi peraturan perundang-undangan yang ada (Makalah disampaikan dalam seminar hukum ikatan notaris Indonesia cabang Jakarta di BPHN. Jakarta, 2020.

Zsazya."OmnibusLawdanRencanaPenerapannya di Indonesia.” https://www.online-pajak. com/, Diakses September 10, 2021. https:// www.online-pajak.com/tentang-pph-final/ omnibus-law. 
HALAMAN KOSONG

516 | Jurnal Penelitian Hukum De Jure Vol. 21 No. 4, December 2021: 507-516 